\title{
URGENSI PENDIDIKAN PADA ANAK USIA DINI
}

Umar Sidiq

Dosen Jurusan Tarbiyah STAIN Ponorogo

\begin{abstract}
Abstrak
Pendidikan anak pada usia dini harus dimulai sejak anak dalam kandungan dengan cara atau teknik pendidikan yang Islami. Anak ketika masih dalam kandungan ibunya, sudah responsif terhadap segala stimulus yang berasal dari lingkungan luarnya yang kadangkadang hal ini tidak disadari oleh seorang ibu. Banyak hadits yang menerangkan tahapan-tahapan pendidikan anak yang bisa kita jadikan pedoman dalam rangka membentuk anak yang shaleh-shalehah dan berguna bagi agama, negara, masyarakat dan kedua orang tuanya.

Kata kunci: Pendidikan dan Anak Usia Dini.
\end{abstract}

\section{Pendahuluan}

Tujuan pendidikan Islam adalah menanamkan taqwa dan akhlaq mulia serta menegakkan kebenaran dalam rangka membentuk manusia yang berkepribadian dan berbudi luhur menurut ajaran Islam. Dasar tujuan pendidikan Islam adalah membimbing pertumbuhan ruhani dan jasmani anak dengan cara mengajarkan, mengarahkan, melatih, mengasuh dan mengawasinya agar berjalan sesuai dengan ajaran agama Islam.

Manusia itu terdiri dari dua unsur, yaitu ruhani dan jasmani. Kedua unsur tersebut berasal dari bahasa Arab, yaitu ruh dan jasad. Ruh biasa diartikan nyawa atau jiwa dan jasad berarti tubuh atau raga, sehingga biasa juga disebut jiwa raga (Abu Bakar Muhammad, tt: 22). Dengan demikian akhir dari tujuan pendidikan Islam adalah penyerahan diri secara totalitas kepada Sang Pencipta Allah Swt. sesuai dengan firman-Nya yang menyatakan bahwa Allah tidak menciptakan jin dan manusia kecuali hanya untuk menyembah kepada-Nya.

Peranan orang tua akan sangat mempengaruhi pola perkembangan anaknya. Baik dan buruk seorang anak ditentukan oleh pendidikan yang diberikan orang tua. Orang tua pada dasarnya berperan penting dalam pembentukan jati diri anak. Setiap bayi yang lahir pada dasarnya berpotensi sama. Allah Swt. telah memberikan pilihan antara jalan yang baik dan 


\section{Umar Sidiq}

buruk yang selanjutnya prosesnya diserahkan kepada orang tua masingmasing. Apabila pasangan orang tua menginginkan anaknya menjadi anak yang baik dari segi jasmani maupun ruhani, maka kesemuanya tergantung pada orang tua, begitu juga sebaliknya, orang tua yang salah atau kurang peduli dalam mendidik anaknya akan mengakibatkan penyimpanganpenyimpangan pada si anak. Penyimpangan tersebut bisa berupa penyimpangan sosial, moral, agama, dan lain-lain.

Pendidikan anak secara aktif, menurut ajaran Islam harus dimulai sejak masa usia anak sudah ada dalam kandungan. Dengan kata lain pendidikan anak pada usia dini harus dimulai sejak anak dalam kandungan dengan cara atau teknik pendidikan yang islami.

\section{Pembahasan}

Pendidikan adalah proses pengubahan sikap tingkah laku seseorang atau kelompok orang dalam usaha mendewasakan manusia melalui sistem pengajaran dan berbagai latihan. Pendidikan secara luas dapat diartikan sebagai semua perbuatan dan upaya yang dilakukan generasi tua untuk mengalihkan pengetahuan, pengalaman dan kecakapan serta ketrampilannya kepada generasi muda sebagai suatu upaya penyiapan pemenuhan kebutuhan baik yang bersifat jasmani maupun ruhani (Hasbullah, 2003: 1).

Sesungguhnya pendidikan adalah masalah penting yang aktual sepanjang zaman. Dengan pendidikan orang menjadi maju. Berbekal ilmu pengetahuan dan teknologi, orang mampu mengolah alam yang dikaruniakan Allah Swt, kepada manusia. Islam mewajibkan setiap lakilaki maupun perempuan untuk menuntut ilmu. Seseorang dianjurkan untuk belajar sejak dari buaian sampai ke liang lahat (Zakiyah Daradjat, 1994: 11).

Binatang bisa dikatakan mendidik anaknya dengan cara melatihnya berjalan, namun pendidikan yang dilakukan binatang hanya terbatas pada pendidikan jasmani. Berbeda dengan manusia, di samping berusaha membawa si terdidik yang belum dewasa ke tingkat kedewasaan dalam arti sadar dan bertanggung jawab atas segala perbuatannya, sang pendidik juga mempunyai tanggung jawab moril dari apa yang telah diajarkannya kepada si terdidik. 
Pendidikan mempunyai fungsi sosial dan individual. Berfungsi sosial karena pendidikan bertugas menolong setiap individu agar dapat menjadi anggota masyarakat yang lebih berhasil dan bermanfaat bagi masyarakatnya. Pendidikan mempunyai fungsi individual karena tugas pendidikan adalah menolong dan membina individu agar dapat menikmati hidupnya yang memuaskan dan berhasil dengan cara mempersiapkan setiap individu dalam menghadapi tantangan kehidupan. Pendidikan adalah proses hidup dan kehidupan umat manusia, maka tujuan pendidikan mengalami perubahan dan perkembangan sejalan dengan perubahan zaman (Zuhairini, 1995: 162).

\section{Tujuan Pendidikan Islam}

Pendidikan dalam bahasa Arab adalah tarbiyah, dengan kata kerja rabba. Kata pengajaran dalam bahasa Arab adalah ta'lim dengan kata kerja 'allama. Pendidikan dan pengajaran dalam bahasa Arab tarbiyah wat ta'lim, sedangkan pendidikan Islam dalam bahasa Arab adalah tarbiyah islamiyah. Pendidikan Islam adalah usaha orang dewasa muslim yang bertaqwa secara sadar mengarahkan dan membimbing pertumbuhan serta perkembangan fitrah (kemampuan dasar) anak didik melalui ajaran Islam kearah titik maksimal pertumbuhan dan perkembangannya (M. Arifin, 2003: 22).

Tujuan pendidikan Islam adalah menanamkan taqwa dan akhlaq mulia serta menegakkan kebenaran dalam rangka membentuk manusia yang berkepribadian dan berbudi luhur menurut ajaran Islam. Dasar tujuan pendidikan Islam adalah membimbing pertumbuhan ruhani dan jasmani anak dengan cara mengajarkan, mengarahkan, melatih, mengasuh dan mengawasinya agar berjalan sesuai dengan ajaran agama Islam. Dengan demikian akhir dari tujuan pendidikan Islam adalah penyerahan diri secara totalitas kepada sang pencipta Allah Swt. sesuai dengan firman-Nya yang menyatakan bahwa Allah tidak menciptakan jin dan manusia kecuali hanya untuk menyembah kepada-Nya.

Tujuan pendidikan Islam menurut Imam al-Ghazali adalah; (1) kesempurnaan manusia yang puncaknya adalah dekat dengan Allah Swt; (2) kebahagiaan manusia yang puncaknya kebahagiaan di dunia dan akhirat, karena itu berusaha mengajar manusia agar mampu mencapai tujuan-tujuan 
yang dirumuskan. Menurut Ahmad D. Marimba, sebagaimana dikutip Nur Uhbiyati (1998: 30), tujuan akhir pendidikan Islam adalah terbentuknya kepribadian muslim.

Konggres pendidikan Islam sedunia tahun 1980 di Islamabad menyatakan bahwa pendidikan Islam harus ditujukan ke arah pertumbuhan dan berkesinambungan dari kepribadian manusia yang menyeluruh melalui latihan spiritual, kecerdasan dan rasio, perasaan dan panca indera. Oleh karenanya, pendidikan harus memberikan pelayanan kepada pertumbuhan manusia dalam semua aspeknya (spiritual, intelektual, imajinasi, ilmiah, jasmaniyah, linguistik, baik secara individual atau kolektif) serta mendorong semua aspek ke arah kebaikan dan kesempurnaan (M. Arifin, 2003: 28).

Menurut Abdullah Khozim, (1982: 89), sudah menjadi kewajiban setiap individu muslim khususnya bagi semua orang tua untuk mendidik dan membina anaknya ke jalan yang sesuai dengan apa yang ada dalam al-Qur'an dan sunah Nabi. Peranan orang tua akan sangat mempengaruhi pola perkembangan anaknya. Baik dan buruk seorang anak ditentukan oleh pendidikan yang diberikan orang tua, sebagaimana dalam salah satu hadits Nabi Saw dikatakan:

"Dari Umar bin Muhammad al-Hamdani, dari Muhammad bin Isma'il al-Bukhori, dari Yahya bin Bukair, dari al-Laits bin Sa'ad, dari Yahya bin Sa'id, dari Suhali bin Abi Shalih, dari ayahnya, dari Abu Hurairah, bahwasanya Rasulullah Saw bersabda: Setiap anak yang lahir ke dunia dalam keadaan fitrah. Maka bapak-ibunyalah yang akan menentukan apakah ia akan menjadi Yahudi, Nasrani atau Majusi." (HR. Ibnu Majah).

Hadits di atas jika dipahami dalam kontek kekinian maka akan mengandung pengertian bahwa orang tua pada dasarnya berperan penting dalam pembentukan jati diri anak. Setiap bayi yang lahir pada dasarnya berpotensi sama. Allah Swt. telah memberikan pilihan antara jalan yang baik dan buruk yang selanjutnya prosesnya diserahkan kepada orang tua masing-masing.

\section{Tahapan-Tahapan Mendidik Anak}

Pendidikan anak secara aktif, menurut ajaran Islam harus dimulai 
sejak masa usia anak sudah ada dalam kandungan. Dengan kata lain pendidikan anak pada usia dini harus dimulai sejak anak dalam kandungan dengan cara atau teknik pendidikan yang Islami. Pandangan Islam ini mengikis beberapa pandangan Barat yang menyatakan bahwa pendidikan anak secara dini harus dimulai ketika anak menginjak usianya yang ke tujuh. Dalam perkembangannya pendapat ini bergeser karena muncul pendapat baru yang menyatakan bahwa pendidikan anak dimulai pada umur empat tahun, ketika anak masuk dalam pendidikan taman kanakkanak. Pendapat ini lama bertahan, tetapi kemudian muncul pendapat yang lebih baru lagi yang menegaskan pendidikan anak dimulai sejak lahir.

Penelitian terakhir di bidang penelitian bayi menyatakan bahwa anak ketika masih dalam kandungan ibunya, sudah responsif terhadap segala stimulus yang berasal dari lingkungan luarnya yang kadang-kadang hal ini tidak disadari oleh ibunya. Penemuan ini dapat diterima oleh umat Islam karena dalam Islam sendiri dinyatakan dalam hadits Nabi Saw:

“Dari A'mas dari Zaid bin Wahab, dari Abdullah, ia berkata: Saya mendengar Nabi Saw bersabda: Sesungguhnya setiap orang dari kamu terkumpul (masa) kejadiannya dalam perut ibunya selama 40 hari dalam bentuk nuthfah, kemudian menjadi 'alaqah selama 40 hari berikutnya, lalu menjadi mudhghah 40 hari selanjutnya. Kemudian diutus kepadanya malaikat lalu dihembuskannya ruh kepadanya."(H.R. Muslim, dalam: Imam Abi Husein Muslim ibn Hajjaj al-Qusyairi alNaisaburi, 2008: 1019).

Hadits ini menjelaskan bahwa proses terjadinya manusia ketika berada dalam perut memiliki tiga tahap yang masing-masing tahap empat puluh hari. Tahap pertama adalah periode perkawinan antara sperma dan ovum dalam rahim. Periode kedua adalah terbentuknya tulang-belulang yang terbungkus daging, dan periode terakhir adalah periode di mana ruh ditiupkan ke dalamnya. Setelah masa ini adalah masa perkembangan janin manusia dalam rahim, dan mulai masa ini pula janin yang ada dalam kandungan sudah dapat merasakan lingkungan yang ada di luarnya.

Berkenaan dengan pendidikan anak saat masih berada dalam rahim ibunya, Rasulullah Saw menyatakan:

"Orang yang celaka adalah orang yang telah (menderita) celaka dalam perut ibunya." (H.R. Muslim). 
"Manusia yang paling jelek adalah manusia yang membuat istri (keluarga) menjadi sempit (susah)." (H.R. al-Thabrani).

Dari kedua hadits diatas dapat disimpulkan, orang yang celaka, berbuat jahat, dan selalu membuat resah masyarakat bukan tidak mungkin karena adanya kelainan yang diterima ibunya ketika ia berada dalam rahim. Di antara contohnya adalah bayi yang tidak direstui kehadirannya oleh orang tua mereka, sehingga mereka enggan untuk merawat bayi tersebut ketika berada dalam perut ibunya, atau bisa juga bayi hasil hubungan gelap, atau mungkin makanan yang dimakan oleh kedua orang tuanya adalah makanan yang tidak halal atau suami sering menganiaya istri dan menyakitinya ketika sang istri sedang mengandung. Kesemuanya ini dapat mengakibatkan lahirnya seorang anak yang tidak sesuai dengan harapan kedua orang tuanya. Anak kemungkinan akan mempunyai kelainan baik kelainan fisik maupun kejiwaannya.

Jika orang tua bermaksud agar anaknya tidak celaka maka ia harus dengan sungguh-sungguh berupaya menghindari perbuatan yang tidak sesuai dengan ajaran Islam sejak dini, ketika anaknya berada dalam kandungan ibunya. Anak yang ada dalam kandungan harus diupayakan kebahagiaannya melalui upaya membahagiakan ibunya. Apabila suami berbuat sesuatu yang membuat susah istrinya yang sedang mengandung, maka dengan sendirinya hal itu secara langsung akan membuat anak yang dikandungnya menjadi susah. Suami yang mengetahui istrinya mengandung harus berupaya membuat istrinya senang, tentram, dan bahagia agar anak yang dikandungnya merasa senang dan bahagia pula.

Mendidik anak dalam kandungan berbeda dengan mendidik anak ketika sudah lahir, karena pendidikan yang diterapkan tidak bisa diberikan secara langsung, melainkan dengan cara memberikan rangsangan-rangsangan yang diperlukan yang diolah secara edukatif melalui ibunya. Rangsangan-rangsangan yang Islami yang dilakukan ibunya akan langsung dapat direspon anak dalam kandungan. Misalnya dengan mengatakan halhal yang baik dan melakukan amal shalih, seperti selalu berdzikir kepada Allah, membaca ayat-ayat al-Qur'an, menghadiri kegiatan pengajian, dan lain-lain. Bayi yang ada dalam kandungan secara otomatis akan merespon apa yang diperbuat ibunya melalui gerakan-gerakan bayi dalam kandungan. 
Memasuki tahapan berikutnya, ketika bayi telah lahir ke dunia, pendidikan yang diberikan orang tua khususnya ibu yang secara langsung berinteraksi dengan anaknya harus ekstra hati-hati dan penuh kesabaran dalam mendidik anak. Pendidikan anak yang dimaksud harus disejajarkan dengan konsep ajaran Islam sendiri yakni menciptakan budi pekerti luhur dan akhlak mulia serta dapat berbakti kepada orang tua, agama, nusa dan bangsa. Tahapan-tahapan yang harus dilakukan dalam mendidik anak sebagaimana sabda Nabi Muhammad Saw:

"Dari Anas r.a. berkata: Nabi Muhammad Saw bersabda: anak yang lahir diaqiqahi pada hari ke tujuh, diberi nama dan dibuang kotoran dari rambutnya. Apabila ia sudah mencapai umur enam tahun, maka dididik sopan santun, apabila ia sudah mencapai umur sembilan tahun maka dipisah tempat tidurnya (antara anak laki-laki dan perempuan), apabila ia sudah berumur tiga belas tahun maka dia harus dipukul jika tidak mau mengerjakan sholat, apabila sudah mencapai umur enam belas tahun maka ayahnya memegang tangannya seraya berkata: "aku sudah mendidikmu, sudah mengajarimu dan sudah menikahkanmu, saya berlindung kepada Allah dari cobaanmu di dunia dan siksamu di akhirat kelak". (H.R. Ibnu Hiban).

Mendidik anak, apalagi ketika ia masih kecil sampai menginjak masa remaja membutuhkan ketelatenan dan kesabaran. Masa-masa ini adalah masa yang paling rawan perkembangan anak di mana pada umumnya anak akan mencari jati diri masing-masing. Agar anak tidak terjerumus ke dalam hal-hal yang tidak diharapkan maka ia membutuhkan didikan dan bimbingan serta pengarahan dari orang tua. Islam sendiri telah mengajarkan bagaimana mendidik anak agar tidak terjebak ke arah perilaku menyimpang.

Dalam hadits diatas disebutkan pendidikan anak mempunyai beberapa tahapan. Tahap pertama, adalah fase di mana anak lahir kemudian kedua orang tuanya melakukan ritual sebagai wujud rasa syukur atas anugerah yang diberikan Allah dengan melakukan penyembelihan hewan yang disebut 'aqiqah dan mencukur rambut. Periode ini merupakan periode persiapan pendidikan anak masa awal setelah lahir. Prosesi 'aqiqah adalah prosesi pembersihan dari segala kotoran yang ada pada si anak, sekaligus harapan agar anak tumbuh sesuai dengan apa yang diharapkan orang tuanya. 


\section{Umar Sidiq}

Masa selanjutnya di mana anak berusia enam tahun merupakan masa penerapan budi pekerti anak kepada orang tua, lingkungan dan juga kepada sang pencipta. Pendidikan yang diajarkan berupa bagaimana seorang anak belajar dan mengamati keadaan sekitar. Usaha untuk meniru segala apa yang dilihat, diamati dan didengar sangat mendominasi sehingga metode pengajaran melalui pemberian contoh akan sangat efektif. Ia harus sudah mulai diajak untuk melaksanakan sholat, membaca, dan lain-lain.

Memasuki usia anak yang ke tiga belas tahun, apabila hal-hal yang telah diajarkan pada waktu usia sebelumnya belum dapat dilaksanakan oleh anak, maka langkah pendidikan dengan disertai "kekerasan" yang diiringi rasa kasih sayang menurut hadits tersebut harus dilaksanakan. Tahap ini adalah tahap pembelajaran anak menuju kedewasaan. Anak sudah dapat membedakan mana yang baik dan mana yang tidak baik. Pendidikan dengan disertai "kekerasan" diperlukan demi menciptakan anak yang bertanggung jawab atas apa yang telah diperbuatnya.

Pendidikan anak pada periode terakhir adalah ketika anak berusia enam belas tahun. Pada usia ini anak sudah dapat berpikir sendiri untuk menentukan sikapnya masing-masing. Keberhasilan pendidikan orang tua yang diterapkan akan dapat terlihat dampaknya pada usia ini. Apabila anak dalam kehidupan sehari-harinya melakukan dan mematuhi apa yang dikatakan orang tuanya maka kemungkinan besar pendidikan yang diterapkan sebelumnya memperoleh kesuksesan. Akan tetapi jika didapati seorang anak sudah berani menentang orang tuanya, ada kemungkinan pendidikan yang ia terima sebelumnya kurang berhasil atau bahkan sama sekali tidak tertanam dalam diri anak.

Kiranya sudah jelas disebutkan dalam al-Qur'an dan lebih diperjelas lagi dalam beberapa hadits Nabi Muhammad Saw, bagaimana mendidik anak agar berhasil. Namun demikian kurangnya kesadaran dan ketelitian orang tua dalam mendidik anak dengan berpegang pada apa yang telah diajarkan Nabi berdampak pada beberapa perilaku yang kadang membuat resah lingkungan. Orang tua mungkin tidak menyadari metode pendidikan anak yang diterapkan Nabi, atau mungkin juga mereka menyadari akan adanya petunjuk tersebut, akan tetapi dalam realitanya masih ada beberapa orang dan mungkin banyak dari mereka yang tidak sempat mengamalkan apa yang telah diajarkan Nabi Saw. Apabila metode pendidikan anak yang 
diajarkan Nabi Saw betul-betul diterapkan oleh umatnya, niscaya perilaku menyimpang dan hal-hal yang dilakukan anak yang tidak sesuai dengan harapan orang tua dan agama tidak akan terjadi.

Materi Pendidikan Islam

Salah satu komponen operasional pendidikan Islam sebagai suatu sistem adalah materi. Materi pendidikan Islam adalah semua bahan pelajaran yang disampaikan kepada peserta didik sesuai dengan tingkat kemampuannya. Materi pendidikan itu berbeda dalam setiap lembaga pendidikan. Semakin tinggi lembaga pendidikan semakin kompleks materi yang dibahas. Dan antara pendidikan umum dengan pendidikan agama juga berbeda materi yang diberikan.

Abdullah Nasih Ulwan (2002: 165-167), membagi materi pendidikan Islam menjadi: (1) pendidikan iman merupakan materi tentang pemahaman anak terhadap dasar-dasar iman, rukun Islam, dan dasardasar syari'ah, sejak anak mulai mengerti dan dapat memahami sesuatu; (2) pendidikan moral sebagai pendidikan tentang prinsip dasar moral dan keutamaan sikap serta watak (tabiat) yang harus dimiliki dan dijadikan kebiasaan oleh anak sejak masa pemula hingga menjadi seorang mukallaf, yakni siap mengarungi lautan kehidupan; (3) pendidikan intelektual yang mengajarkan sesuatu bermanfaat, seperti: ilmu-ilmu agama, kebudayaan, bahasa dan sebagainya. Hal itu untuk mencetak anak-anak yang berkualitas dan siap menghadapi tantangan zaman; (4) pendidikan kejiwaan adalah mendidik anak supaya bersikap berani terbuka, mandiri, suka menolong, bisa mengendalikan amarah, dan senang kepada seluruh keutamaan jiwa dan moral secara mutlak; (5) pendidikan sosial, sebagai makhluq sosial manusia atau anak tidak bisa hidup tanpa bantuan orang lain. Mereka berinteraksi antara yang satu dengan yang lainnya. Untuk itu diperlukan pendidikan sosial kepada anak sejak dini, agar dalam masyarakat nantinya dia dapat bergaul dengan baik, bertindak bijaksana, dan tidak dikucilkan dari kelompoknya.

\section{Metode Pendidikan Islam}

Abdullah Nasih Ulwan (2002: 1), berpendapat bahwa metode yang digunakan dalam pendidikan Islam yang sesuai dan berpengaruh pada anak usia dini adalah sebagai berikut: (1) pendidikan dengan keteladanan; 


\section{Umar Sidiq}

(2) pendidikan dengan adat kebiasaan; (3) pendidikan dengan nasehat;

(4) pendidikan dengan memberikan perhatian; (5) pendidikan dengan memberikan hukuman.

Pertama, pendidikan dengan keteladanan. Keteladanan dalam pendidikan merupakan metode yang berpengaruh dan terbukti paling berhasil dalam mempersiapkan dan membentuk aspek moral, spiritual, dan etos sosial anak. Mengingat pendidik adalah seorang figur terbaik dalam pandangan anak, yang tindak tanduk dan sopan santunnya akan ditiru oleh mereka. Bahkan bentuk perkataan, perbuatan, dan tindak tanduknya akan senantiasa tertanam dalam kepribadian anak. Oleh karena itu, masalah keteladanan menjadi faktor penting dalam menentukan baik atau buruknya anak (Abdullah Nasih Ulwan, 2002: 142).

Kedua, pendidikan dengan adat istiadat. Sejak kecil, anak harus sudah dibiasakan dengan pendidikan yang baik. Anak lahir dalam keadaan suci, dengan fitrah tauhid yang murni, agama yang benar, dan iman kepada Alloh, baik dan buruk tingkah laku anak tergantung dari pendidikan yang diberikan oleh lingkungan sekitarnya. Anak dilahirkan dengan naluri tauhid iman kepada Alloh. Dari sini tampak peranan pembiasaan, pengajaran, dan pendidikan bagi pertumbuhan dan perkembangan anak dalam menemukan tauhid yang murni, budi pekerti yang mulia, rohani yang luhur, dan etika religi yang lurus (Abdullah Nasih Ulwan, 2002: 185). Lingkungan dan adat kebiasaan yang baik mempunyai pengaruh besar terhadap pendidikan Muslim dalam kebaikan dan ketaqwaan, juga terbentuknya atas dasar iman, akidah, dan akhlaq yang baik, serta terbiasa bertata krama, bermoral baik, dan berkebiasaan yang mulia.

Ketiga, Pendidikan dengan nasehat. Metode dengan nasehat dapat membukakan mata anak-anak tentang hakekat sesuatu dan mendorongnya menuju perilaku luhur, memberi nasehat untuk berakhlaq mulia, dan membekali anak dengan prinsip-prinsip Islam. Nasehat yang tulus berbekas dan berpengaruh jika memasuki jiwa yang hening, hati terbuka, akal yang bijak dan berfikir. Nasehat juga akan meninggalkan bekas yang sangat mendalam dan mendapat tanggapan secepatnya. Metode dalam al-Quran menyajikan nasehat dan pengajaran mempunyai ciri tersendiri, yakni: (1) seruan yang menyenangkan seraya dibarengi dengan kelembutan; (2) metode cerita disertai perumpamaan yang mengandung pelajaran dan 
nasehat; (3) metode wasiat dan nasehat dalam al-Quran yang mengandung arahan kepada pembaca terhadap sesuatu yang mendatangkan manfaat dalam agama, dunia, dan akheratnya.

Keempat, pendidikan dengan memberikan perhatian. Anak mulai dari kecil sudah dapat merasakan adanya perhatian, baik itu dari orang tuanya maupun dari orang-orang di sekitarnya. Dia sudah dapat merasakan orang yang menyayanginya dan orang yang membencinya. Untuk itu, pendidik harus memperhatikan pendidikan anak mulai dari perkembangan jasmani, ruhani, mental, tingkah laku, pemikirannya, agar dalam perkembangannya anak tidak terjerumus ke jurang kehancuran dan kebinasaan.

Kelima, pendidikan dengan hukuman. Dengan memberikan hukuman kepada anak yang bersalah, akan membuat anak jera dan berhenti berperilaku buruk. Tanpa pemberian hukuman kepada anak yang bersalah, maka anak akan mengulangi lagi perbuatannya. Dalam hal ini hendaknya pendidik bijaksana dalam menggunakan cara memberi hukuman yang sesuai, tidak bertentangan dengan tingkat kecerdasan anak, pendidikan, dan pembawaannya. Di samping itu, hendaknya ia tidak segera menggunakan hukuman kecuali setelah menggunakan cara-cara lain. Hukuman adalah cara yang paling akhir (Abdullah Nasih Ulwan, 2002: 315).

Melihat kenyataan bahwa anak usia dini, dalam perkembangannya membutuhkan pendidikan yang serius, karena usia dini adalah sebagai dasar dari pendidikan di usia-usia selanjutnya, maka metode-metode diatas sangatlah tepat untuk mendidik anak usia dini. Dan sebagai pendidik harus pandai-pandai memilih metode yang tepat dan efektif, disesuaikan dengan situasi dan kondisi pendidikan.

Dengan demikian hal itu disesuaikan dengan kondisi anak pada usia dini, karena di sini seorang pendidik Islam bertanggung jawab mengasuh anak didiknya dengan cara-cara tertentu. Pendidikan haruslah menggunakan suatu metode yang bervariasi, memilih waktu yang tepat, bersikap lemah lembut agar pendidikan yang diberikan kepada anak didiknya mudah diterima.

\section{Psikologis Pendidikan Islam pada Anak Usia Dini}

Pendidikan agama pada anak usia dini merupakan pendidikan agar anak yang dilahirkan nantinya menjadi anak yang shaleh. Demikian juga 


\section{Umar Sidiq}

waktu dalam kandungan anak sudah dapat menerima pengaruh dari ibunya. Untuk itu seorang ibu yang mengandung hendaknya berhati-hati dalam bertingkah laku dan bertutur kata. Pada periode bayi, perkembangannya belum dapat diketahui secara jelas karena anak bersifat pasif, terutama bila yang dimaksud dalam melakukan amaliah-amaliah keagamaan. Anak masih sangat tidak berdaya, aktifitasnya terbatas pada tidur, menyusu, menangis, bermain, belajar duduk, merangkak, berdiri, dan berjalan. Pengamalan tahap agama sudah dapat dilakukan sejak dini. Orang tua dapat melatih dengan kalimat-kalimat tayyibah (baik) seperti melafalkan basmalah setiap kali menyusui, ketika mengambilnya dari tempat tidur, memandikannya, sehingga anak terbiasa mendengar kata-kata yang baik dan suatu saat anak akan menirukannya. Dan pada dasarnya anak selalu aktif mencari atau mengenal sesuatu yang baru baginya.

Pada usia dini, anak mengenal Tuhan melalui bahasa, dari kata-kata orang di sekitarnya. Tuhan bagi anak masih fantasi atau gambarannya disamakan dengan makhluq hidup atau manusia (anthrophomorphonisme), misalnya anak yang sangat kritis dalam hal menanyakan Tuhan (Imam Bawani, 1997: 92-93). Usia dini adalah saat yang tepat untuk menanamkan pendidikan, saat yang paling peka dalam pertumbuhan dan perkembangan anak untuk menerima pengaruh pendidikan. Untuk itu, para pendidik terutama orang tua harus menanamkan pendidikan pada diri anak sedini mungkin.

Pada tahun-tahun pertama dari pertumbuhan, anak belum mampu dan hanya menguasai perbendaharaan kata-kata yang terbatas, serta mereka belum mampu memahami kata-kata yang abstrak. Mereka dapat merasakan sikap, tindakan, dan perasaan orang tua. Mereka akan merasakan apakah disayang atau justru dibenci oleh orang lain. Usia dini dikatakan masa kritis, karena pada usia ini diletakkan dasar-dasar daripada bermacammacam pola tingkah laku, bermacam-macam sikap terhadap orang lain maupun terhadap dirinya sendiri. Pola-pola tingkah laku itu sebagian besar dibawa untuk selanjutnya dapat menentukan sukses tidaknya seseorang dalam menyesuaikan diri pada kehidupan dikemudian hari.

\section{Penutup}

Pendidikan anak secara aktif, menurut ajaran Islam harus dimulai sejak anak masih berada dalam kandungan. Dengan kata lain pendidikan 
anak pada usia dini harus dimulai sejak anak dalam kandungan dengan cara atau teknik pendidikan yang Islami. Mendidik anak dalam kandungan berbeda dengan mendidik anak ketika sudah lahir, karena pendidikan yang diterapkan tidak bisa diberikan secara langsung, melainkan dengan cara memberikan rangsangan-rangsangan yang diperlukan yang diolah secara edukatif melalui ibunya. Rangsangan-rangsangan yang Islami yang dilakukan ibunya akan langsung dapat direspon anak dalam kandungan. Misalnya dengan mengatakan hal-hal yang baik-baik dan melakukan amal shalih, seperti selalu berdzikir kepada Allah, membaca ayat-ayat alQur'an, menghadiri kegiatan pengajian dan lain-lain. Bayi yang ada dalam kandungan secara otomatis akan merespon apa yang diperbuat ibunya melalui gerakan-gerakan bayi dalam kandungan.

Memasuki tahapan berikutnya, ketika bayi telah lahir ke dunia, pendidikan yang diberikan orang tua khususnya Ibu yang secara langsung berinteraksi dengan anaknya harus ekstra hati-hati dan penuh kesabaran dalam mendidik anak. Pendidikan anak yang dimaksud harus disejajarkan dengan konsep ajaran Islam sendiri yakni menciptakan budi pekerti luhur dan akhlak mulia serta dapat berbakti kepada orang tua, agama, nusa dan bangsa.

Masa selanjutnya dimana anak berusia enam tahun merupakan masa penerapan budi pekerti anak kepada orang tua, lingkungan dan juga kepada sang pencipta. Pendidikan yang diajarkan berupa bagaimana seorang anak belajar dan mengamati keadaan sekitar. Usaha untuk meniru segala apa yang dilihat, diamati dan didengar sangat mendominasi sehingga metode pengajaran melalui pemberian contoh akan sangat efektif. Ia harus sudah mulai diajak untuk melaksanakan sholat, membaca dan lain-lain.

Memasuki usia anak yang ke tiga belas tahun, apabila hal-hal yang telah diajarkan pada waktu usia sebelumnya belum dapat dilaksanakan oleh anak, maka langkah pendidikan dengan disertai kekerasan yang diiringi rasa kasih sayang harus dilaksanakan. Tahap ini adalah tahap pembelajaran anak menuju kedewasaan. Anak sudah dapat membedakan mana yang baik dan mana yang tidak baik. Pendidikan dengan disertai kekerasan diperlukan demi menciptakan anak yang bertanggung jawab atas apa yang telah diperbuatnya.

Pendidikan anak pada periode terakhir adalah ketika anak berusia 
enam belas tahun. Pada usia ini anak sudah dapat berfikir sendiri untuk menentukan sikapnya masing-masing. Keberhasilan pendidikan orang tua yang diterapkan akan dapat terlihat dampaknya pada usia ini. Apabila anak dalam kehidupan sehari-harinya melakukan dan mematuhi apa yang dikatakan orang tuanya maka kemungkinan besar pendidikan yang diterapkan sebelumnya memperoleh kesuksesan. Akan tetapi jika didapati seorang anak sudah berani menentang orang tuanya, ada kemungkinan pendidikan yang ia terima sebelumnya kurang berhasil atau bahkan sama sekali tidak tertanam dalam diri anak.

\section{Daftar Pustaka}

Arifin, M. (2003). Ilmu Pendidikan Islam. Jakarta: Bumi Aksara

Bawani, Imam. (1997). Perkembangan Jiwa Anak Usia Balita: Stratifikasi dan Pembinaan Agama. Surabaya: Bina Ilmu

Daradjat, Zakiyah. (1994). Pendidikan Islam dalam Keluarga dan Sekolah. Jakarta: Ruhama

Hasbullah, (2003). Dasar-dasar Ilmu Pendidikan. Jakarta: Raja Grafindo Persada

Ibn Hajjaj al-Qusyairi al-Naisaburi dan Imam Abi Husein Muslim, (2008). Shahih Muslim Beirut: Darul Kutub

Khozim, 'Abdullah. (1982). Muqorrir al-Hadits. Saudi Arabia: Mamlakah 'Arobiyah al-Su'udiyah

Muhammad, Abu Bakar. (t.t.). Membangun Manusia Seutuhnya Menurut al-Quran. Surabaya: al-Ikhlas

Nasih Ulwan, Abdullah. ( 2002). Pendidikan Anak dalam Islam. Jakarta: Pustaka Amani

Uhbiyati, Nur. (1998). Ilmu Pendidikan Islam. Bandung: Pustaka Setia Zuhairini, (1995). Filsafat Pendidikan Islam. Jakarta: Bumi Aksara 